\title{
The environment: once a problem for the rich, now part of the marketing strategy? A case study on China's environmental communication
}

\author{
Valeria Zanier \\ Department of East Asian Studies \\ Ca' Foscari University of Venice \\ Palazzo Vendramin de' Carmini \\ Dorsoduro 3462 - 30123 Venezia, Italy \\ E-mail: zanier@unive.it
}

\begin{abstract}
After a long history of overexploitation and destruction of its natural resources, China has begun to include environmental protection among its economic development priorities. From the 1990s, the government has started to take important steps in this direction, by signing all relevant major international agreements, setting stricter measures to keep pollution out of densely populated areas and launching a number of eco-friendly projects aimed at enhancing 'environmental consciousness' in Chinese citizens. What level of environmental consciousness can be found in Chinese contemporary society? Are Chinese consumers ready for the so-called responsible consumption? What value do Chinese citizens attach to 'nature', 'the environment', 'responsible consumption'? Assuming it is rather difficult to give exhaustive answers, the author will try to shed some light on these issues through the analysis of an innovative project, which is going to reshape the island of Chongming, in Shanghai Municipality, into an environmentally friendly island.
\end{abstract}

Keywords: communication; community; environment; propaganda; sustainable development.

Reference to this paper should be made as follows: Zanier, V. (2008) 'The environment: once a problem for the rich, now part of the marketing strategy? A case study on China's environmental communication', Int. J. Chinese Culture and Management, Vol. 1, No. 2, pp.232-243.

Biographical notes: Valeria Zanier holds an MA in Foreign Modern Languages (University of Perugia, 1996) and a Postgraduate Diploma in International Trade (Italian Trade Commission, Ca' Foscari University of Venice, Oriental Institute of Naples, 1997). After working as an Adviser in international trade for the China-Italy Chamber of Commerce in Beijing and other firms/institutions (1998-2003), Ms. Zanier embraced the research field within the frame of China's history after 1949. Her lines of enquiry include economic reforms, private entrepreneurship and the discourse on economic development. She is now completing the Doctoral Programme in Oriental Studies at Ca' Foscari University of Venice, where she is also a Lecturer in the Chinese Language. 


\title{
1 Introduction
}

\author{
"We must make conserving energy, decreasing energy consumption, protecting \\ the environment and using land intensively the breakthrough point and main \\ fulcrum for changing the pattern of economic growth." \\ Premier Wen Jiabao, opening the annual session of the National People's \\ Congress (NPC), Beijing, 5 March 2007.
}

After a long history of overexploitation and destruction of its natural resources, China has begun to include environmental protection among its economic development priorities. From the 1990s, the government has started to take important steps in this direction, by signing all relevant major international agreements and setting stricter measures to keep pollution out of densely populated areas. ${ }^{1}$

As a key feature of the efforts made to counter China's image as environmentally degraded, the government has been launching a number of eco-friendly projects aimed at enhancing 'environmental consciousness' in Chinese citizens. Such projects, which involve private and public intervention, include 'eco-tourism' parks and guesthouses (nongjia le), 'green' resorts, 'eco-friendly' housing and, possibly, even 'green' work sites for local citizens.

The research questions posed by the present study are the following: What level of environmental consciousness can be found in Chinese contemporary society? Are Chinese consumers ready for the so-called responsible consumption? What value do Chinese citizens attach to 'nature', 'the environment', 'responsible consumption'?

Assuming it is rather difficult to give exhaustive answers, the author will try to shed some light on the above-mentioned issues through the analysis of a relevant eco-friendly project - the 'Chongming eco-island project'. By focusing on the communication strategy employed by local institutions and private partners to 'sell the project', the study will examine the language and the rhetoric used in public and private communication to present the project to society.

\section{Methodology}

The research has privileged the following lines of enquiry: identifying discursive objects and speaking subjects; analysing rhetorical strategies; identifying and analysing recurrent concepts and terminology. Descriptions of Chongming Island, as well as identification of the benefits offered by the project, proved particularly valuable in achieving an environmental 'imagery' ideally shared by Chinese civil society.

Critical Discourse Analysis as elaborated by outstanding scholars such as Van Dijk and Fairclough (Van Dijk, 1985; 1988; 1997; Fairclough, 1992; 1995), and guidelines for analysis in the study of language and ideology (Zhao and Hackett, 1998; Hodge and Kress, 1979; Hodge and Louie, 1998) will provide the methodological framework.

Sources of information include promotional material released by the Chongming and Shanghai Municipal Governments, as well as Shanghai Industrial Investment (Holdings) Co., Ltd (later on to be called SIIC), on their websites, and articles that appeared in the national and local press in the period July 2001-April 2005. Newspapers include People's Daily, China Daily, Shanghai Star, Jiefang Daily, Wenhui Bao, Legal Daily, and Science and Technology Daily. 
The texts of speeches collected during some presentation workshops for the project provided a substantial basis for the research. Personal communication between the author and representatives of the government of Chongming Prefecture, the Shanghai Environmental Protection Bureau (EPB) and SIIC, as well as a number of interviews with Chongming residents, provided contextual data for the textual analysis.

\section{Case study}

Chongming is located north of Shanghai at the mouth of the Yangtze (Changjiang) River. It was formed from the accumulation of massive silt deposits flowing down through the river. Covering $1200 \mathrm{sq} \mathrm{km}$ and increasing in size by about 500 ha annually through the deposition of sand, silt and mud by the river, it is the world's largest alluvial island and China's third largest island. It supports a population of about 735000 people. $^{2}$

Its coastal wetland and tidal flats provide many important ecological services, including buffers against tidal surges and staging areas for migratory birds. Owing to its scenic qualities, and its proximity to the city of Shanghai (45 km away), the island is also an attractive tourist destination.

Chongming's economy has traditionally relied on agriculture, especially rice fields. Industry on the island only developed in the late 1970s, including machinery, textiles, ship repair, biomedicine, telecommunications, chemicals, food processing and building materials.

In the last 20 years, the structure of the local economy has changed in favour of the industrial sector, with fisheries keeping their key role. Real estate is a booming sector: in 2004 total investment increased by $87.7 \%$.

At the end of the 1990s, Shanghai's Municipal Government and the city's Urban Planning Administration set the guidelines for an ambitious ecological project, which it is claimed will completely reshape Chongming into an environmentally friendly island by $2020 .^{3}$ According to the master plan, the island will be divided into five parts, each developing eco-friendly industries and/or services:

1 eastern area - recreational activities and international exchanges

2 central area - central forest area; residential area for leisure, rest, educational purposes

3 northern area - theme parks and exhibition area for biological agriculture

4 southern area - centre for rural urbanisation

5 western area - ecological scenery area and holiday resort; convention centre.

A combined bridge and tunnel project (total length $25.5 \mathrm{~km}$ ) will shorten journeying time to the Shanghai City Centre from over two hours to $45 \mathrm{~min}$. The island will eventually exploit its tourism potential and become a high-end residential area for commuters to Shanghai, attracting a far larger number of visitors, residents and cars. The tunnel/bridge project is due to be completed by 2009, just in time for 'Shanghai Expo 2010'. As government slogans promise, the construction of a modern integrative eco-island (现代化的综合性生态岛 xiandaihua de zonghexing shengtai dao) will be a strategic move for the improvement of sustainable development in Shanghai. Chongming Island will become 'Shanghai’s garden' (上海“后花园' Shanghai hou huayuan). ${ }^{4}$ 


\section{The Chenjia Town (Dongtan) residential projects}

Among the projects to be realised on the island, the residential projects designed for the area of Chenjia Town, Dongtan (southeast part of Chongming Island) offer a peculiar appeal for research purposes. There, a Sustainable Development Dream Town - Eco-Village (可持续发展的理想城市一生态农庄 kechixu fazhan de lixiang chengshi - shengtai nongzhuang) is to be built for established and newly arrived inhabitants of the island. The project, including Dongtan International Wetland Park in the east, Tourist Leisure Zone in the south, Chenjia Town and port area in the West, and an Agroforestry Industrial Park in the north, dates back to the end of 1998, when Shanghai Industrial Investment (Holdings) Co., Ltd (SIIC) was granted by the Shanghai Municipal Government the integral management right to the Dongtan area. From 2000 onwards, many consulting companies from all over the world have been cooperating with SIIC to set up a successful project for the creation of an eco-city in Dongtan. It was only at the beginning of 2005 that ARUP, the leading UK planning, engineering and consultancy firm, was eventually chosen by SIIC as its partner. ${ }^{5}$ According to the jointly developed project, Dongtan will be designed to ensure that all its citizens will be in close contact with nature and wildlife. There will be green spaces and corridors, lakes and canals. Besides being a green city in appearance, Dongtan will also be such in the way it functions: its buildings will be highly energy efficient, it will be powered by renewable energy, and all its waste will be recycled and composted.

The way it has been promoted to potential partners and inhabitants, the project is to make use of high-end technologies, aiming at developing low-impact consuming patterns. The city is going to host a 'community' of people, who will ideally share the values of ecological sustainable development and desire an urban development in harmony with nature. The following are the guidelines of the development of Chenjia Town, Dongtan, as exposed by SIIC managers and local government officials during a promotional tour in Europe: 6

- clean energies

The 'community' will make use of solar energy, wind energy, geothermal energy, biomass energy and other renewable energy sources.

- $\quad$ saving as a pattern of consumption

The 'community' will make limited use of heavy packaged products and disposable goods.

- ecological architectural techniques

All the buildings in the 'community' will be erected using ecological techniques. The construction of every single building will help to improve achievements in energy savings.

- $\quad$ organic composition of the city

In the 'community', every building will be linked to the others by means of ecological corridors.

- reuse of waste water

All water in the 'community' will have to undergo biological treatment. All organic waste will be reused by turning waste into renewable energy. 
- conservation of the natural environment

Great care will be taken with the city's overall production of $\mathrm{CO}_{2}$ and oxygen.

- Wired city

The entire 'community' will use high-technology mobilisation. Each house will have its own remote-control system, so that every resident will be able to control the safety conditions of every appliance by using video-phone, portable video-phone and computer.

ARUP first thought of Dongtan as an ideal development of the garden cities created in Europe in the 20th century, following the concepts of 'garden city' and 'social city'. Such concepts were introduced by Howard (1898) in the late 19th century and greatly influenced many residential projects in Europe during the first half of the 20th century. ${ }^{7}$ The first garden city was created in Letchworth, $60 \mathrm{~km}$ north of London, in 1903; the second in Welwyn, $35 \mathrm{~km}$ north of London, in 1920. Built outside the possible commuter range, such cities were intended as 'self-contained communities' for living and working, with large green areas for residents. As a matter of fact, all these cities (as well as those which were built later on, such as Milton Keynes, Northampton or Peterborough) very soon became part of the city of London, transforming themselves into big commuter catchments, with little or no life of their own.

In very recent times, the UK Government has started to develop a new model, called the 'Sustainable Communities Strategy' (2003), aiming at developing and ameliorating a ring of satellite towns (70 or $130 \mathrm{~km}$ from London), where people live mainly on local jobs. In this way, the local communities would end up living in better organised cities, getting better infrastructure and better social environments. In some way, Dongtan could be a suitable place to host a 'sustainable community' of people who would deliberately choose Chongming as their residence.

\title{
5 Imagery of the Chongming Island project
}

\begin{abstract}
"The aim of the plan for the development of Chongming Island is by 2020 to develop an exquisite eco-environmental brand; [...] to turn the island into the integrative eco-island of the cosmopolitan city of Shanghai, wiping out the gap between the city and the countryside; $[\ldots]$ into an international sea garden on the Pacific Ocean; [...] to turn Chongming into a model zone demonstrating domestically and internationally the achievements of human eco-development combining the characteristics of the cosmopolitan Shanghai and the Yangtze River area."

崇明岛域的规划发展目标是, 到 2020 年, 建设成为以优美的生态环境为品牌, [ $\cdots]$ 城乡融合的上海国际大都市的综合型生态岛区, 西太平洋沿岸的国际性海上花园, $[\cdots$.$] 成为国内领先、国际一流的具有长江口地域特色和上海大都市特点的人类生$ 态发展模式示范地区. 8
\end{abstract}

This is a passage taken from Jiefang Daily, the most authoritative Shanghai Party paper, reporting a speech by Shanghai Party Commissioner Gong Xueping. Wenhui Bao, a more popular Shanghai local paper, reports the same speech more concisely: 
"By 2020 Chongming will be turned into 'the Green Island on the Yangtze River Estuary' and it will be the 'eco-model for the development of a harmonious relation between mankind and Nature'."

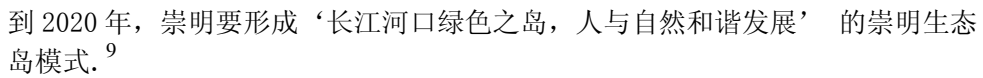

This promotional material often recalls traditional symbols already widely used in advertising language: words such as garden (Shanghai garden, Shanghai's international garden on the Pacific Ocean), treasure/precious (precious island, treasure island, which is also the name of a well-established tourist resort on Chongming Island), dream/ideal (ideal city). They all convey a uniform image of a 'consumer paradise', where everything is beautiful, sparkling, easy and - above all - ready to please the consumer.

At times the communicative approach is to stress the project's innovative qualities, praising Chongming's attention to environmental protection, even suggesting that embodied in the project are high principles going well beyond mere innovative residential standards:

"[Dongtan] is going to become a model ecological town with the highest suitability for inhabitation. With regards to an effective social development, the development of Chongming should move away from the clone of lifestyles of the industrial age and aim towards innovative urban development and lifestyles, building Chongming as an eco-friendly post-industrialization city. Advancing into the 21 st century, living standards measures will shift from quantity to quality, from material to spiritual, and from interior to exterior. However, Shanghai is limited in large-scale, comprehensive and ecological functional space. Chongming must be developed with a genuine aim to create ecological residential areas and eco-cities in order to promote the inhabitability of Shanghai as a metropolis and draw a higher standard of professionals."10

Regardless of its governmental or corporate origin, this 'appeal to new consumers' is especially visible in the promotional material for residential projects in Chenjia Town, Dongtan. The language refers to new living standards, based on 'quality' and 'spiritual' measures. Concepts and ideas such as 'eco-friendly post-industrialisation city' and 'clone of lifestyles of the industrial age' depict a China already weary of the benefits of the 'consumer paradise', and thus wishing to project a responsible way of living. The future eco-city of Chenjia Town embodies a new philosophy of life, which only a new category of illuminated citizens will be able to grasp:

"Developing an eco-friendly residential industry in order to [...] attract people with high revenues and high education level and make them choose Chongming as their residence."

(有序推进各类生态型的房地产业的发展, 吸引一定规摸的较高收入人群和较高 文化知识的人群入住崇明). ${ }^{11}$

"The area will develop as a model-zone for the green consumer. There will be limited access for heavy packaged products, disposable goods will be reduced, excessive consumption. Excessive eating and drinking behavior will be prevented."

The types of imagery displayed in the promotional material produced on the Chongming project can be traced back to different communication strategies: 
- The first strategy makes use of traditional symbols already widely used in advertising language. These symbols are, for example, garden (Shanghai garden, Shanghai's international garden on the Pacific Ocean); treasure/precious (precious island, treasure island); dream/ideal (ideal city). They all convey a uniform image of a 'consumer paradise'.

- The second strategy proposes innovative concepts, such as responsible consumption or quality, as opposed to quantity, thus calling on new consumers to play an active part in the Chongming project. Descriptions of the Dongtan eco-village as an "eco-friendly post-industrialization city" or exhortations to "abandon the clone of lifestyles of industrial era" transmit the image of a country already weary of the benefits provided by the 'consumer paradise'.

The first type of imagery may be categorised as part of a traditional marketing strategy, expressing positive and good values in order to inspire confidence in citizens and attract them to a beautiful world. This set of values refers to what we may call the first stage of the consumerist society. Whoever has experienced living in China for some time knows that TV commercials, street ads and shopping malls spread a highly uniform vision of the consumer paradise. These values are probably not so different from those that we may find in other newly developed countries, where citizens are happy to have the means to buy household appliances and to live more comfortably. What is peculiar to China is the fact that this consumerist vision is also very visible in the media, informing popular information channels as well as more party-oriented organs.

The second strategy belongs to a subsequent stage, when the 'new consumer', concerned about the damage caused, appears onstage. In European countries and others of more mature development, this event had already occurred some time ago and we are now confronted with a number of individuals and consumer organisations that show a well-developed environmental consciousness.

In China, many citizens make their purchases in order to enhance their social status and show how successful they are. The need for 'responsible consumption' is new. Passages such as the ones quoted propose an image of the Chinese citizen already projected towards a 'responsible lifestyle', a citizen who does not care for buying consumer goods and is not eager to build successful images of himself/herself through what he/she buys. He is just weary of the consumerist vision and ready to embrace eco-friendly consumption.

There is also a third kind of strategy, which does not strictly belong to marketing, but is part of the party rhetoric and shapes its ideological discourse. The Chongming eco-friendly project will play an important role in giving China a 'green' face. Developing an environmentally friendly image will add to China's international prestige, contributing to building a good image of China abroad. This is how national pride is projected onto environmental concerns, making use of environmental consciousness to get back into the world, gain a good reputation, strengthen national identity and achieve a higher position.

The Chongming eco-island project is presented as a project that gives China a 'green' image. The objective of the marketing strategy is first of all to convince Chinese citizens that, thanks to Chongming, China is proficient in environmental protection. As many Chinese already know, environmental protection is very highly valued by the international community. The strategy's further aim is to project China's green image onto the world stage. 
Stressing the values of national pride and of 'face', the marketing strategy refers to a wider concept: China's progress makes the country a worthy member of the international community. This aspiration arises from a background of long years of isolation, which is still in the memory of Chinese citizens. Such a message can be found very often in media discourse on economic development, where it is usually delivered in speeches by government officials. It also appears in the mouths of the representatives of China's social elite, such as entrepreneurs or urban residents.

Unsurprisingly, I found many examples in news released by the government. Here is how SIIC, the developer, describes Chongming's appealing advantages: ${ }^{12}$

\begin{abstract}
"Creating an international ecological reputation - In terms of an effective environmental development, Chongming's natural resources possess particular assets that enable it to reach world-class levels. [...] In this way, Shanghai's ecological demands necessary for modernization in the 21 st century can be greatly enhanced, expanding Shanghai's eco-friendly areas, fitting for every large, modernized and international city. At the same time, Chongming Island's unique estuary ecosystem features can help ensure that Shanghai becomes a world-class city with a reputation that offers competitiveness combined with an ecological image."

"Chongming's green development [..] should be comparable to international practices in order that the achievements and results are of a world-class level. Our company suggests that in terms of the ecological economy Chongming aims to become listed as a model area for green industrial parks approved by the UN Industry Development Organization. With respect to its development of residential areas, Chongming should aim to be listed in the program of sustainable residential areas initiated by the UN Residential Bureau, and in terms of eco-construction, Chongming should aim to be listed in the 'Global Top 500 areas in Eco-construction', initiated by the UNCDE.,"10
\end{abstract}

In order to project a green image to the world, China really needs to show that there is widespread attention to the side effects of development. Of all the analysed material, only China Daily and Shanghai Star, which are English-language newspapers obviously directed at the foreign community, have been raising questions regarding the impact that such an increased number of cars and people will have on the island. However, the tone is not too dramatic.
"With the linking of the island with the main part of Shanghai with a new tunnel and bridge in 2007, people fear passengers and vehicles will destruct and pollute the environment."
"Experts suggest enhancing the appraisal and monitoring system of the natural environment on the island." 13

\title{
6 The appeal to popular consensus and support
}

Projects like Chongming need the agreement and participation of the population as a whole. The farmer, a nearly forgotten figure in contemporary Chinese media, enters the arena, as shown by this article in the Shanghai Star: ${ }^{14}$

\footnotetext{
"Song Youfa, a local farmer on Chongming Island, is extremely busy even when it is not harvest season. His three-storey house is a destination for tourists from Shanghai and neighbouring cities [...] Song takes pride in his experience of hosting President Hu Jintao on July 27th."
} 
The farmer, both as a speaking subject and as a discursive object, is used to convey positive messages. To whom is the message directed? Probably to the new consumers, who are supposed to be motivated by a responsible concern towards society and who are possibly active in the creation of a 'harmonious society' where all social strata coexist peacefully:

\begin{abstract}
"The guidelines of compiling the 'Chongming Master Plan' are: [...] in the frame of modern ecological education, to promote harmonious and effective solution to the problems related to the countryside, farmers and agriculture, in order to handle at best the relationship between eco-development and the welfare of the society."

编制《崇明岛域总体规划纲要》的指导思想是坚持: [ ․]在现代生态产业培育中推 进城乡融合, 有效解决农村、农民和农业问题, 处理好生态发展与社会富裕的关系. ${ }^{15}$
\end{abstract}

The intention of the political leadership is to provide an innovative message by linking environmental protection to the market and by highlighting the harmonious relationship between man and nature. At the same time, in between the lines, we can read very precise indications to citizens as to what is to be considered 'correct' and 'good'. Chongming Island is being referred to as a good model.

In domestic communication, the government presents the Chongming project to Chinese citizens as one of national interest, a 'good' project, something really worth doing for the country and for Shanghai. This pattern reminds us of 'propaganda campaigns', highly rhetorical language that stresses values such as 'harmony between mankind and nature' (人和大自然和谐交融) and describes 'the incomparable ecological advantage' of Chongming Island (无可比拟的生态优势). The local government website reports that "the People of Chongming had glorious revolutionary tradition in history" (崇明人民具有光荣的革命传统). ${ }^{16}$

As in the socialist media tradition, the party official is the speaking subject instructing citizens on the good things to do in a nationalistic spirit.

"The guidelines for 'the Chongming Master Plan' are: first of all, to adhere to
the road of development in the frame of an ecological modernization, thus
cutting across the traditional industrialization."

编制 《崇明岛域总体规划纲要》的指导思想是坚持：第一, 坚持走一条跨越

传统工业化的生态型现代化的发展之路. ${ }^{15}$

Looking closer at recent communication activities in Chongming Island proper, it becomes more and more evident how the government's presence is actually felt everywhere. A special effort has been made to obtain the agreement of Chongming residents: in 2004 the 7th Festival of Arts and Culture was organised following the theme of Greenness (“绿满瀛洲', Luman Yingzhou). More than 150 performances were shown to an audience of more than $150000 .^{16}$

At the end of July 2004, President Hu Jintao paid a visit to the island. In that month, local papers gave more extensive coverage of Chongming events. Jiefang Daily quotes part of Shanghai Party Commissioner Gong Xueping's speech in mid-July:

"We must publicize extensively the [island Master] plan in order to secure consensus and support from the people on the island." 
These references to popular consensus and support bring back memories of mass participation in the 1950s and 1960s. If we only look back to revolutionary years, we will find many episodes when human action was used to transform nature: terracing steep rocky mountains and recovering farmlands from rivers and lakes ('in agriculture, learn from Dazhai', 农业学大寨 nongye xue Dazhai, 1963-1964); bad water management (such as large dam construction in Gezhou and Sanmenxia); deforestation ('The Three Big Cuts', 三大发 san da fa, as the first step of the Great Leap Forward 1957-1958); elimination of 'enemy' animals (rats, sparrows, flies and mosquitoes; 'Wipe out the four pests', 除四害 chu si hai, 1958). During those years, following Chairman Mao's motto 'Encircle the Lakes, Create Farmland' (围湖造田 wei hu zao tian), the Chinese masses transformed their environment all over the country. The guiding principle was: 'Man must conquer nature' (人定胜天 ren ding sheng tian). Do contemporary Chinese citizens maintain that 'transforming nature' is still necessary in order to obtain development? This is very difficult to assess.

\section{Conclusions}

From the material I collected and analysed, the Chongming project seems to embody all those elements that are part of modern sensitivity to nature and the environment. In some respect, however, it seems that only in these model zones are humans and nature able to have a balanced relationship. Providing citizens with appropriate tools to get introduced into modified zones, modelled after close observation of nature and well-protected against man-made damage, conveys rather artificial messages. Maybe humans and nature have almost nothing in common. The natural environment is by itself not enough to satisfy human needs and it is necessary to rebuild or remould it after human needs. Images such as 'exquisite ecological brand' recall the creations of the language of advertising, while at the same time reminding us that a director is guiding action from 'above'.

Not much seems to have changed since revolutionary times, when Mao was passing ideological sentences against Nature, except that now those ideological sentences and campaigns are intended in Nature's favour. ${ }^{18}$ Jiang Hong, a geographer who has been doing extensive comparative analyses on environmental policies in China before and after 1978, thus describes the attitude towards nature in contemporary China:

$$
\begin{aligned}
& \text { "underlying environmental destruction and ecological construction appear to be } \\
& \text { a very similar ideology, one that is based on the utilitarian value of the } \\
& \text { environment and on the assumption of nature's inadequacy." }
\end{aligned}
$$

On the sociological perspective, Chenjia Town, Dongtan, offers many interesting aspects for an innovative analysis of China's emerging middle class. It would be really challenging to conduct a survey on those 'enlighted' citizens with high revenue who will deliberately choose Chongming as their new residence. The concept of a 'sustainable community' would be a good reference point to test how successful are the government's efforts to build new social settings. Unfortunately, for the time being, the 'sustainable community' only exists in the developers' master plan. We may see appeals to 'sustainable community' members in the loads of communication material produced by SIIC, ARUP and the local government. We may see traces of green and responsible 
consumers in the discourse on the Chongming project. Yet, as a matter of fact, in summer 2007, the Chenjia Town, Dongtan residential projects were still at a very early stage of development and only some relocation projects of local citizens into new compounds had taken place. We still have to wait to get real evidence of the possibility that a 'sustainable community' might set up in Dongtan - and in China.

\section{References}

ARUP (2006) Shanghai Dongtan: An Eco-city, Shanghai: Shanghai Sanlian Shudian.

Chan, G. (2004) 'China's compliance in global environmental affairs', Asia Pacific Viewpoint, April, Vol. 45, No. 1, pp.69-86.

Fairclough, N. (1989) Language and Power, London: Longman.

Fairclough, N. (1992) Discourse and Social Change, Cambridge: Polity Press.

Fairclough, N. (1995) Media Discourse, London: Edward Arnold.

Hodge, R. and Kress, G. (1979) Language as Ideology, London: Routledge.

Hodge, R. and Louie, K. (1998) The Politics of Chinese Language and Culture: The Art of Reading Dragons, London: Routledge.

Howard, E. (1898) Tomorrow: A Peaceful Path to Real Reform, London: Swann Sonneschein.

Mol, A.P.J. (2003) 'Environment, modernity and transitional China. At the frontier of ecological modernization', Environmental Governance in Asia: New State-Society Relations, INREF-AGITS Conference, Chiang Mai: Chiang Mai University, 10-12 October, pp.62-82.

Shapiro, J. (2001) Mao's War Against Nature. Politics and the Environment in Revolutionary China, Cambridge: Cambridge University Press.

Van Dijk, T.A. (1988) News as Discourse, Hove and London: Lawrence Erlbaum Associates, Publishers.

Van Dijk, T.A. (1997) Discourse Studies: A Multidisciplinary Introduction, London: Sage.

Van Dijk, T.A. (Ed.) (1985) Handbook of Discourse Analysis, London: Academic Press.

Zhao, Y. and Hackett, R. (1998) Sustaining Democracy? Journalism and the Politics of Objectivity, Toronto: Garamond Press Ltd.

\section{Notes}

1 In 1992, China was one of the first countries to adopt and promulgate Agenda 21. Agenda 21 is the UN's Action Plan for sustainable development in the 21st century. It was defined in Rio de Janeiro during the 1992 UN Conference on Development and Environment, and has been subscribed to by 180 governments all over the world. An 800-page document, Agenda 21 propounds the principle of sustainable development, defined as balancing the fulfilment of human needs with the protection of the natural environment so that these needs can be met not only in the present, but in the indefinite future. For a comprehensive vision of the environmental question in China, cf.: World Bank's annual reports on worldbank.org, and environmental reports published by the State Environmental Protection Bureau (SEPA), on www.zhb.gov.cn/english/. Other valuable works are Chan (2004) and Mol (2003).

2 Its terrain is flat and completely covered by a porous stratum from the Quaternary Period. There are no hills or mountains, but the terrain is higher in the northwest and central parts and slightly lower in the southwest and east. This is probably the origin of the name, which in Chinese means 'above the water and flat land'. 
3 The first project which will start construction is Chongming Dongtan Technical Experimental Station, which will be jointly developed by SIIC and Shanghai East China University. Immediately after this will be Dongtan Biological Agriculture, a project developed by SIIC and the Italian Ministry of the Environment. Other projects include Protection and Sustainable Management of Dongtan Natural Resources (wetlands; fisheries system); and Exploitation and Usage of Dongtan Renewable Energies - Hydrogen Energy.

4 Jiefang Daily website, 8 April 2005.

5 In the month of November 2005, SIIC and ARUP signed an agreement confirming their common will to develop the world's first eco-city at Dongtan. The agreement was witnessed by Chinese President Hu Jintao and British Prime Minister Tony Blair.

6 Chongming Workshop, Venice, 15 January 2005. For a more complete presentation of the Dongtan projects, cf. SIIC Dongtan Investment and Development (Holdings) Co. Ltd. documents and ARUP (2006).

7 Howard (1898), quoted in SIIC Dongtan Investment and Development (Holdings) Co. Ltd. documents and ARUP (2006).

8 崇明岛域总体规划 2020 年将建成国际上海花园 ('Chongming Island Master Plan will in 2020 build Shanghai international garden'), in Jiefang Daily, 7 July 2004.

9 龚学平在市人大常委会听取规划汇报时建议 崇明岛规划将专门立法 ('In the Party City Commission Gong Xueping listens to the report on Chongming Island Master Plan and gives some advice'), in Wenhui Bao, 7 July 2004.

10 www.dongtan.biz

11 Chongming Workshop, Venice, 15 January 2005.

12 The discourse is apparently directed to a Chinese audience, but - as it appears in the sources already translated into English - it may well be considered to be directed to a foreign readership as well.

13 'Chongming Island goes "green”, China Daily, 15 September 2004.

14 Shanghai Star, 25 November 2004.

15 打造上海世界级城市的生态岛和海上花园《崇明岛域总体规划纲要》简介 http://cmx.sh.gov.cn/ $\mathrm{cmzfw} / \mathrm{cmgh} / \mathrm{cmgh}$.aspx.

16 http://cmx.sh.gov.cn/cmzfw/cmgk/cmgk.htm

17 Jiefang Daily, 14 July 2004. 'Publicise' and 'propaganda' are both translations of the Chinese word 宣传 (xuanchuan). There is a current tendency among those Chinese accustomed to an international audience to use the softer translation of xuanchuan into 'publicise'.

18 For a more complete account of Mao's environmental policy, see Shapiro (2001). 